\title{
Analysis of Seismic Action on the Tie Rod System in Historic Buildings Using Finite Element Model Updating
}

\author{
Suzana Ereiz, Ivan Duvnjak *, Domagoj Damjanović (D) and Marko Bartolac (D) \\ Faculty of Civil Engineering, University of Zagreb, 10000 Zagreb, Croatia; suzana.ereiz@grad.unizg.hr (S.E.); \\ domagoj.damjanovic@grad.unizg.hr (D.D.); marko.bartolac@grad.unizg.hr (M.B.) \\ * Correspondence: ivan.duvnjak@grad.unizg.hr
}

\section{check for} updates

Citation: Ereiz, S.; Duvnjak, I.; Damjanović, D.; Bartolac, M. Analysis of Seismic Action on the Tie Rod System in Historic Buildings Using Finite Element Model Updating. Buildings 2021, 11, 453 https://doi.org/10.3390/ buildings 11100453

Academic Editors: Francisco

López Almansa and

Alessandra Aprile

Received: 30 July 2021

Accepted: 29 September 2021

Published: 2 October 2021

Publisher's Note: MDPI stays neutra with regard to jurisdictional claims in published maps and institutional affiliations.

Copyright: (c) 2021 by the authors. Licensee MDPI, Basel, Switzerland. This article is an open access article distributed under the terms and conditions of the Creative Commons Attribution (CC BY) license (https:// creativecommons.org/licenses/by/ $4.0 /)$.

\begin{abstract}
Historic buildings have a high architectural value and their maintenance, repair and rehabilitation require a special approach. This approach is mainly based on the buildings' performance under non-destructive tests such as operational modal analysis (OMA). Under extreme loads, such as earthquakes, these buildings require representative numerical models to simulate their expected response. In historic buildings, tie rods transfer axial loads and are typically used to balance horizontal trust due to static and dynamic loads associated with seismic actions. It is very important to determine the possibility of exceeding their load-bearing capacity under extreme loads, such as an earthquake. In this context, this paper presents an approach for the analysis of seismic action on the tie rod system in a historic building. The analysis was performed by combining the on-site experimental testing and the finite element model updating (FEMU) of the local models of tie rods and the global model of the structure. It was shown that the combination of analyzing local and global structural models, experimental on-site testing and FEMU is a viable solution for assessment of historic buildings' load bearing capacity.
\end{abstract}

Keywords: seismic actions; tie rod system; finite element model updating (FEMU); structural health monitoring (SHM); mode shapes; natural frequency

\section{Introduction}

The use of stone or masonry elements in buildings is one of the oldest methods still in use today. The durability of historical buildings is proven by the number of such structures which are still in use. Because of their high mass, the problem of high compressive forces occurs in the elements of structures built from stone. This problem is particularly interesting in buildings whose load-bearing systems are arches, buttresses, vaults, walls, and domes. The load-bearing system is mainly supported by masonry walls. The walls must support this load in such a way that only compressive stresses occur in them. This is achieved by making the load-bearing system much heavier or thicker. In order to keep these dimensions within certain limits characteristic of stone and masonry, the horizontal components of the compressive forces are balanced using tie rods [1]. These structural elements control the horizontal forces and displacements caused by static and dynamic loads associated with seismic actions. In extreme cases, they can reach the maximum load-bearing capacity by being subjected to high stresses and pulled out of their anchorage (Figure 1). Therefore, the value of the axial force in such systems is often a topic of discussion. There are several uncertainties in determining the axial force value in this type of structural element, which include the complex boundary conditions [2-5] and geometrical and material properties [6]. Several approaches are used to estimate the force values in tie rods-static [7], dynamic [8], and mixed approaches [9]. In this paper, the previous approaches are only mentioned, while their detailed description can be found in [10]. 


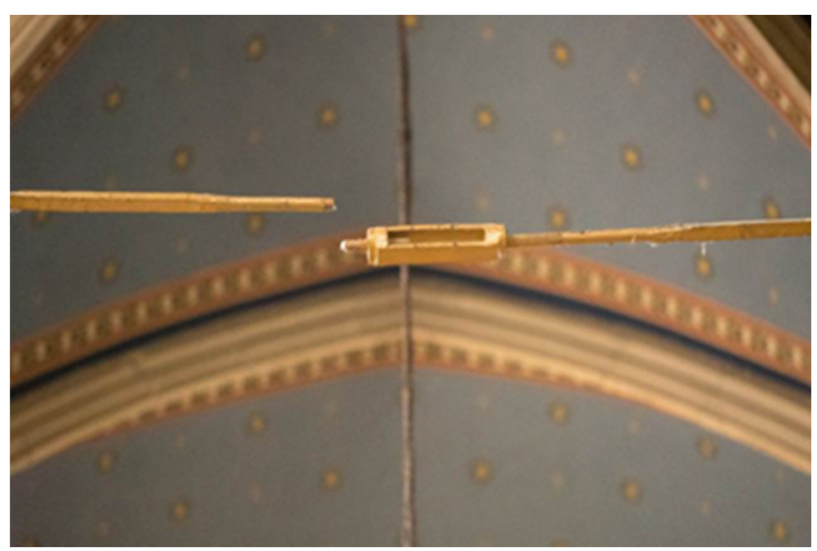

(a)

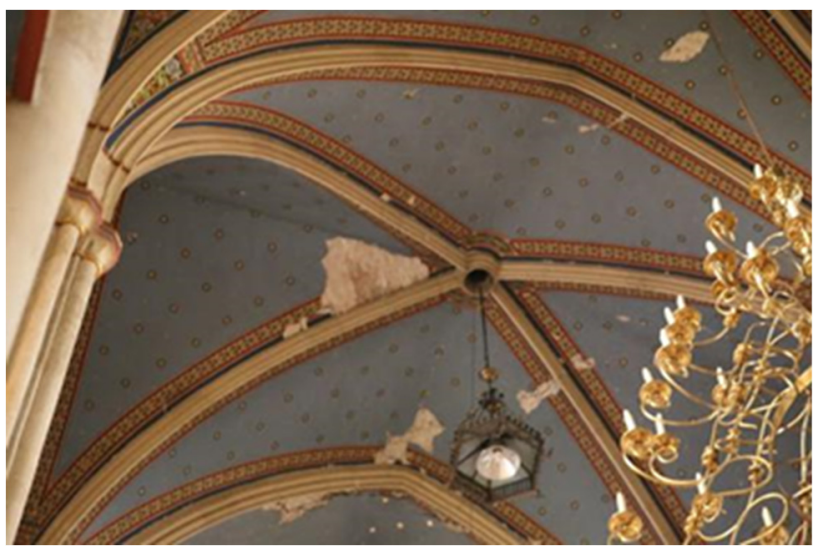

(b)

Figure 1. Cathedral of the Assumption of Mary, Zagreb: (a) Fractured tie rod after its load bearing capacity was reached (b) Damaged vaults after the March 22nd 2020 Zagreb earthquake.

In addition to the above-mentioned approaches, a combination of experimental onsite testing and numerical analysis based on the model updating approach can also be used. Model updating was developed in the 1990s as a topic of great importance to the design, construction and maintenance of mechanical systems and structures [11]. It refers to updating the finite element (FE) numerical model to adopt more precise and accurate structural dynamics parameters based on the known dynamics or statical parameters obtained through experimental investigations of a structure [12-16] (Figure 2).

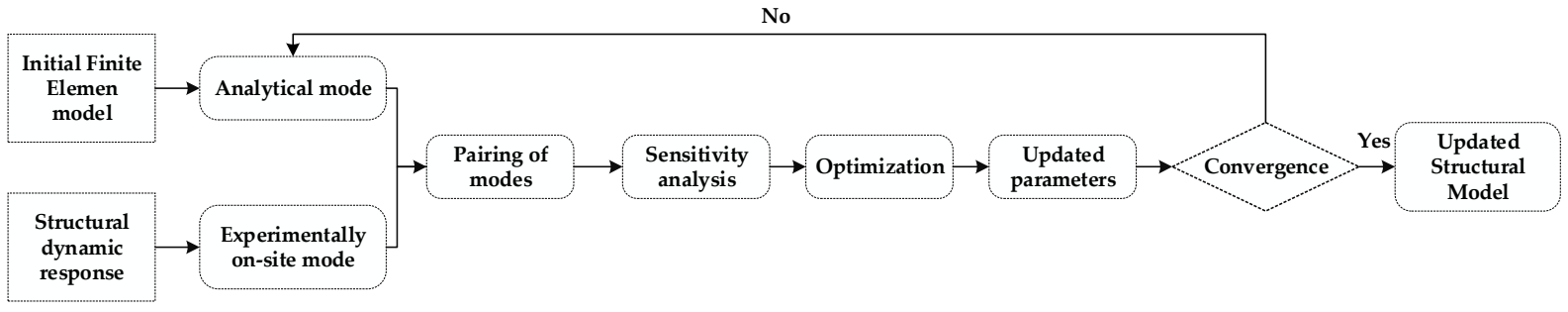

Figure 2. Classical finite element model updating procedure.

During the model updating procedure, the most commonly used model updating parameters are the material [16-23] and geometrical characteristics [23-26] and boundary conditions [27-29], but their selection is generally based on performing the sensitivity analysis [30]. The selection of materials and the definition of their properties cause great difficulties in the development of a numerical model due to their specific mechanical properties. For historical buildings, it is difficult to obtain documentation that provides exact, reliable information about the used material and its properties. Except for the problem of the availability of documentation, an experimental approach to determine the properties is challenging because it requires quite extensive non-destructive testing [31-34]. Regarding the geometric issues, historic buildings are also known for their complex geometry, resulting from the use of different types of structural elements such as vaults, arches, columns and domes. Moreover, the integrations of very slender and massive elements, for example, columns and walls, are common. The aforementioned causes of complex geometry require special attention when modelling these structural elements and their connections. The complexity of finite elements and the ways in which they can be connected, as well as the modelling of connections, have been addressed in several studies [35-38]. Although for some buildings there is no project documentation, nowadays the geometry is not a major problem, as there are several modern methods that can be used to determine the geometry very easily [39-42]. Besides the correct definition of the geometrical and material properties of the numerical model, the boundary conditions are also very important and have an im- 
pact on the dynamic behavior of the structure. When developing a numerical model, their definition can be very demanding and challenging, especially since the scatter of results for different boundary conditions can be very high [43-45]. Experimental investigations are the best control and help to define the boundary conditions of the model. Using experimentally determined structural dynamic parameters (natural frequencies, mode shapes, damping ratios) together with the model updating methods, it is possible to predict the unknown system properties of a real structure (geometry, material properties, boundary conditions) with quite high accuracy and reliability [46-48]. This paper is an extended version of the paper published in [49]. We extend our previous work by performing the operational modal analysis of the cathedral (Figure 3) to determine the mode shapes of the entire structure, that we used to validate the FE model and to update the finite element model.

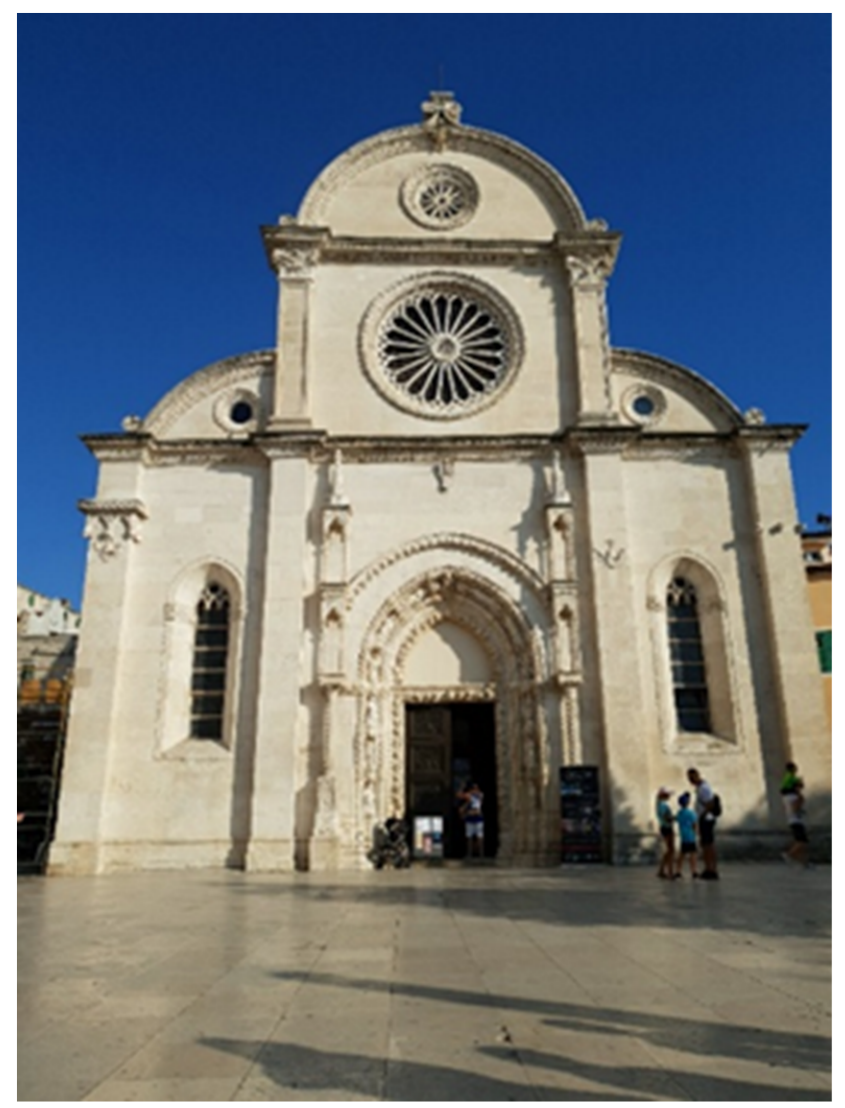

(a)

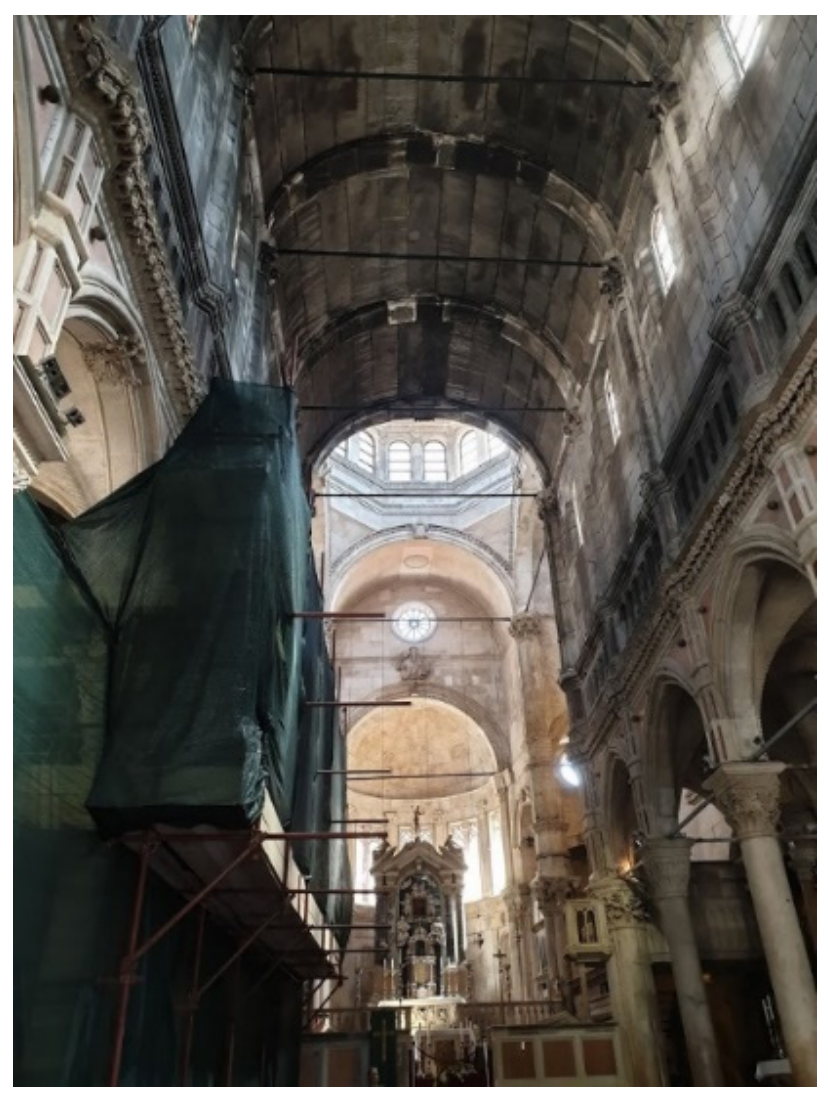

(b)

Figure 3. Cathedral of St. James in Šibenik: (a) West facade (b) System of tie rods inside.

Based on the experimental testing and the application of operational modal analysis (OMA), the structural dynamics parameter, natural frequencies and mode shapes of the whole structure and tie rods were determined. The initial values of the forces in the tie rods were taken from authors' previous paper [10]. The initial numerical model of the cathedral was iteratively updated based on the experimentally determined mode shapes and natural frequency values of the cathedral. In order to select the model updating parameters, a sensitivity analysis was performed. Based on this analysis, the stone masonry elasticity modulus and the boundary conditions were selected as the model updating parameters. Since there were few selected updating parameters, the FEMU was performed with manual updating. After the initial state of the tie rods was obtained, and the global numerical model of the cathedral was updated, an analysis of the internal forces and stresses levels in the tie rods caused by the characteristics of the seismic action for the Šibenik area was 
performed. On this basis, it was determined whether the tie rods will reach their maximum load-bearing capacity during an earthquake.

In the following text, Section 2 describes the procedure of the experimental determination of the structural dynamic parameters of tie rods and the cathedral; Section 3 describes the numerical analysis of the initial numerical model of the cathedral; Section 4 describes the procedure of model updating; Section 5 presents the results of the analysis of internal forces and stresses levels in the tie rods due to seismic action; and Section 6 presents the resulting discussion and conclusions.

\section{Experimental Analysis}

Within the experimental investigation of St. James Cathedral in Šibenik (Croatia), operational modal analysis (OMA) was used to determine the structural dynamic parameters of the whole structure and the tie rods [10]. The description of the structure and the experimental determination of the dynamic parameters of the tie rods can be found in [10], while the experimental investigation of the cathedral will be described in the following text.

\subsection{Experimental Investigation of the Structure}

The experimental investigation of the structure was performed by using piezoelectric accelerometers (PCB Piezotronics, type 393B31 with nominal sensitivity of $10 \mathrm{~V} / \mathrm{g}$, PCB Piezotronics, Depew, NY, USA), an analyzer (Bruel and Kjaer, type 3560c, Bruel and Kjaer, Nærum, Denmark) and associated software. The measurement points were defined in 9 axes in the transverse direction (axes 1-9), 4 axes in the longitudinal direction (axes A-D) (Figure 4a), and in 5 axes along the height of the structure (axes R1-R5) (Figure 4b) according to accessibility within the structure. The measurement was performed at each of the measuring points in two perpendicular directions, $x$ and $y$ (Figure 4a). In this way, 216 measuring points were obtained, the sum of which corresponds to two horizontal directions. The reference measuring point was set at point $7 \mathrm{C}$ at level R3.

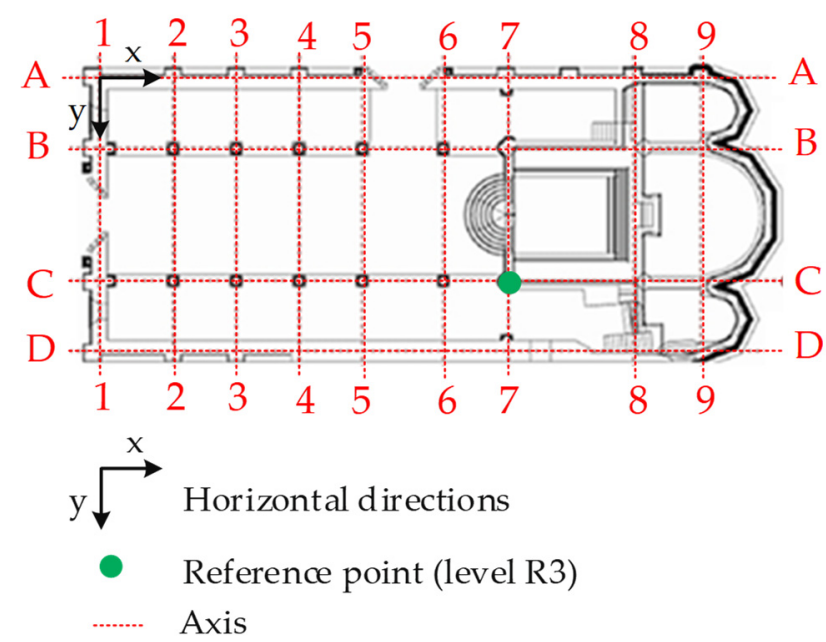

(a)

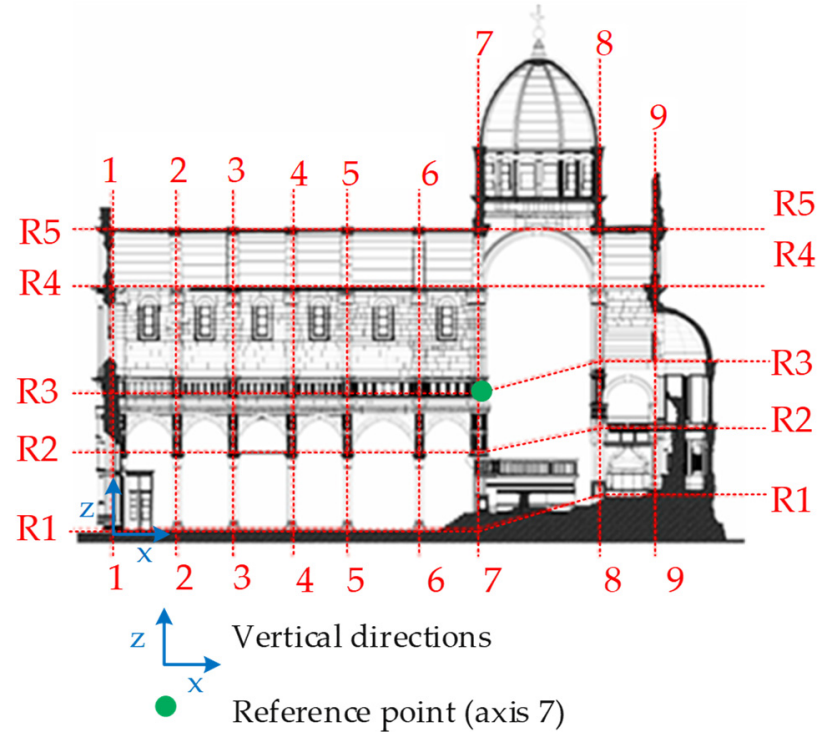

(b)

Figure 4. Cathedral of St. James in Šibenik: (a) Ground floor; (b) Cross-section.

The mode shapes (Figure 5) and natural frequency values (Table 1) were obtained during ambient excitation. Frequency domain decomposition (FDD) and enhanced frequency domain decomposition (EFDD) were used to estimate the modal parameters. The values of the experimentally obtained natural frequencies (Table 1) for the concerned mode shapes (Figure 5) were read from the characteristics record (Figure 6) 


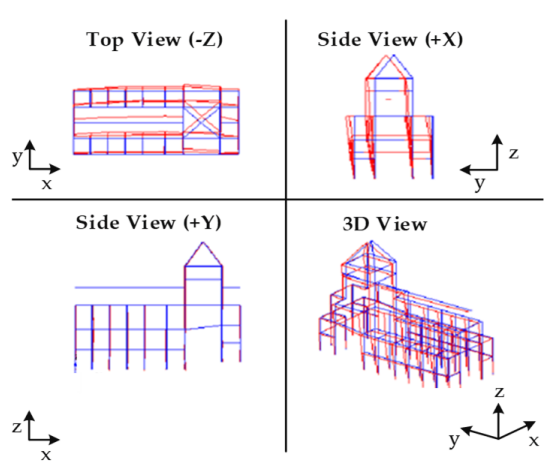

(a)

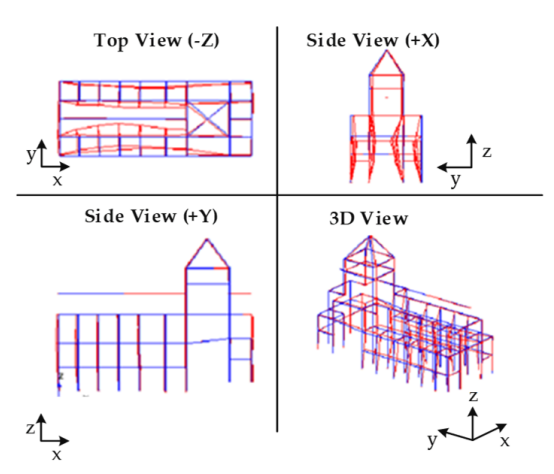

(b)

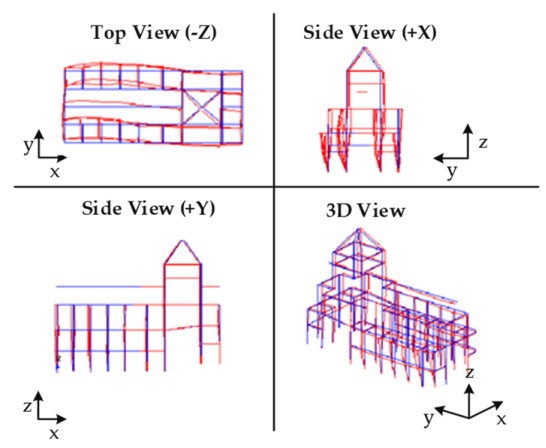

(c)

Figure 5. Experimentally obtained modal shapes of the St. James Cathedral in Šibenik: (a) first, (b) second and (c) third modal shape.

Table 1. Experimentally obtained natural frequency values of St. James cathedral in Šibenik.

\begin{tabular}{ccc}
$\begin{array}{c}\text { Mode, } \\
n\end{array}$ & $\begin{array}{c}\mathbf{f}_{\mathbf{n}}^{\mathbf{e x p}} \\
\mathbf{( H z )}\end{array}$ & Direction \\
\hline 1 & 3.75 & Bending around $\mathrm{x}$ axis, symmetrical \\
2 & 5.55 & Bending around $\mathrm{x}$ axis, antimetrical \\
3 & 5.85 & Second bending mode shape around the $\mathrm{x}$ axis \\
\hline
\end{tabular}

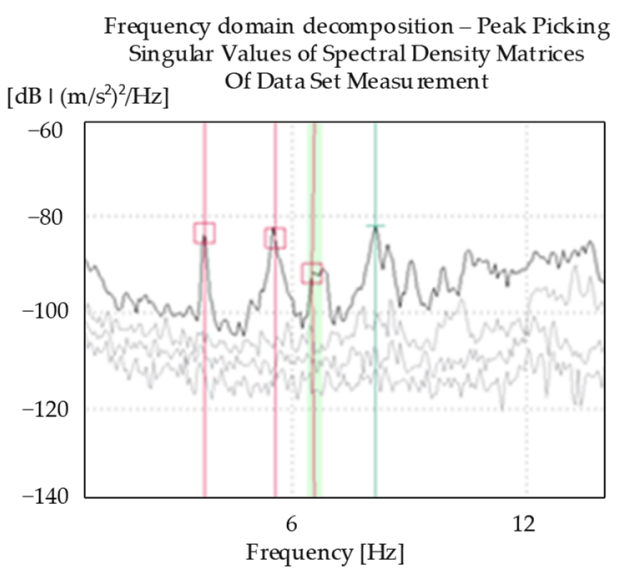

Figure 6. Characteristics record of frequency domain decomposition (FDD) for determination of natural frequencies of the St. James Cathedral in Šibenik (red and green lines indicate the dominant natural frequencies associated with mode shapes present on Figure 5). 


\subsection{Experimental Investigation of Tie Rods}

In addition to the natural frequencies and mode shapes of the whole structure, dynamic parameters of the tie rods were also obtained. Since the tie rods system consists of aluminum and steel tie rods, for simplicity one aluminum and one cast steel tie rod were taken as a reference. A more detailed analysis was performed on these tie rods, as described in [10]. The analysis is based on the use of the experimentally determined natural frequency values and mode shapes to update the finite element model of the tie rods. In addition, the existing equations for determining the axial force values in tie rods were corrected according to the updated finite element model of the tie rods. As the results are shown in [10], for simplicity they will not be described in this paper.

\section{Numerical Analysis}

The experimentally obtained results were used to update the numerical model of the tie rods and the cathedral. Both the local model of tie rods and the global model of the cathedral were developed in SAP 2000 (Computers and structures, Walnut Creek, CA, USA). The numerical model of tie rods was modeled as the Euler Bernoulli beam element with the released bending and torsional moment. In the global model of cathedral columns, arches and tie rods were developed as a beam element, while walls, roof, and floors were developed as a tick shell element. A detailed description of the numerical model of tie rods can be found in [10], while the global model of the cathedral is described in the next subsection.

\subsection{Initial Numerical Model of the Cathedral}

Based on the existing drawings and available 3D scans, a numerical model of St. James Cathedral in Šibenik was developed. From 3D scans and the obtained cross sections of the cathedral, the geometry of the initial numerical model was first developed in AutoCAD (Autodesk AutoCAD 2019, educational, Portland Oregon), after which it was imported into SAP. After importing the model, the elements are associated with the corresponding geometric and material characteristics. As part of the FEMU, static and dynamic analysis was performed by associating the mechanical characteristics of the material and determining the natural frequencies and mode shapes of the whole structure. The values of elastic modulus and material density of cast steel are adopted from the previous paper [10] while the material properties of the aluminum were determined using the same procedure as for the cast steel tie rods. The obtained properties of the aluminum tie rods were: $70 \mathrm{GPa}$ for elastic modulus and $2660 \mathrm{~kg} / \mathrm{m}^{3}$ for material density. For the stone masonry, material density was $2490 \mathrm{~kg} / \mathrm{m}^{3}$ and the modulus of the elasticity was assumed as $20 \mathrm{GPa}$. The material behavior of stone was described by linear theory and homogeneous behavior was assumed. The sum of the material characteristics assigned to different cross-section properties of the global model of St. James Cathedral is shown in Table 2.

Table 2. Material characteristics assigned to the different cross-section properties of the global numerical initial model of St. James Cathedral in Šibenik.

\begin{tabular}{ccc}
\hline Material & $\begin{array}{c}\text { Material Density, } \\
\boldsymbol{\rho}\left(\mathbf{k g} / \mathbf{m}^{\mathbf{3}}\right)\end{array}$ & $\begin{array}{c}\text { Elasticity Modulus } \\
\mathbf{E}(\mathbf{G P a})\end{array}$ \\
\hline Stone & 2491 & 20 \\
Cast Steel & 7697 & 185 \\
Aluminum & 2660 & 70 \\
\hline
\end{tabular}

The numerical model was described using the finite element method (FEM). The size of the walls' finite elements was chosen according to the approximate dimensions of the stone blocks with which the cathedral was built, and it was $0.5 \mathrm{~m} \times 0.5 \mathrm{~m}$. Thickness values of stone blocks were read from the 3D scans of the cathedral and are different for different parts of the cathedral $(0.45-1.00 \mathrm{~m})$. In the area around the opening, portal, stained glass, rosette, the size of the finite elements was adjusted so that their shape can better describe the real situation 
and not affect possible errors in calculation. Since the various roof slabs and a half-domes are connected to the walls of the east facade, the finite elements were adjusted. The finite elements in this part of the structure were meshed more densely and mostly described by triangular finite elements. The complete numerical model is shown in Figure 7.

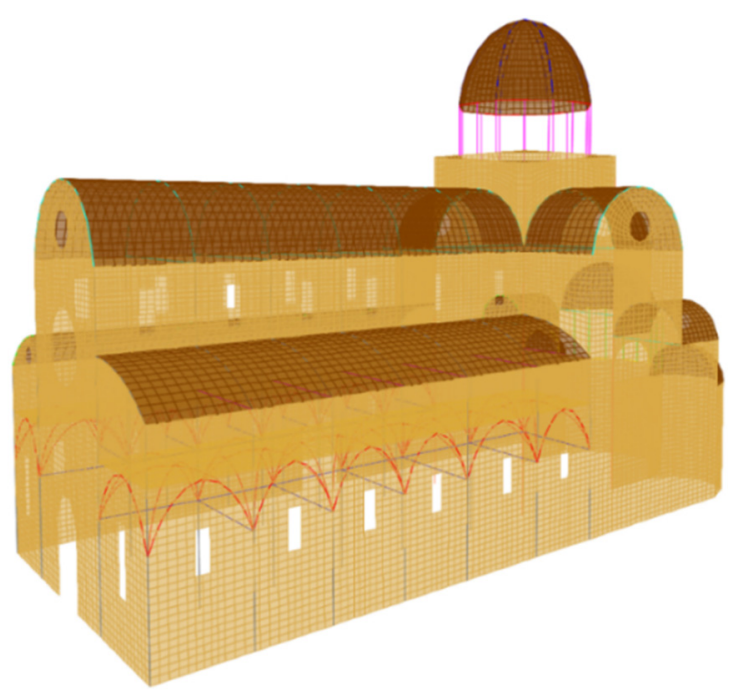

Figure 7. Initial numerical model of the St. James Cathedral in Šibenik.

The tie rod system is put into the three levels, and it was modeled as a series of beam elements clamped into walls and columns with the cross Section $55 \mathrm{~mm} \times 55 \mathrm{~mm}$ to $60 \mathrm{~mm} \times 60 \mathrm{~mm}$ for cast steel tie rods and $30 \mathrm{~mm} \times 50 \mathrm{~mm}$ for aluminum tie rods. Their initial stress was obtained using the previously described method presented in [10]. The results of the initial stress calculation of the tie rod for each level of the structure can be seen in Figure 8. According to the obtained values of the stress level, in the global numerical model of the cathedral, the tie rods are subjected to axial tension.

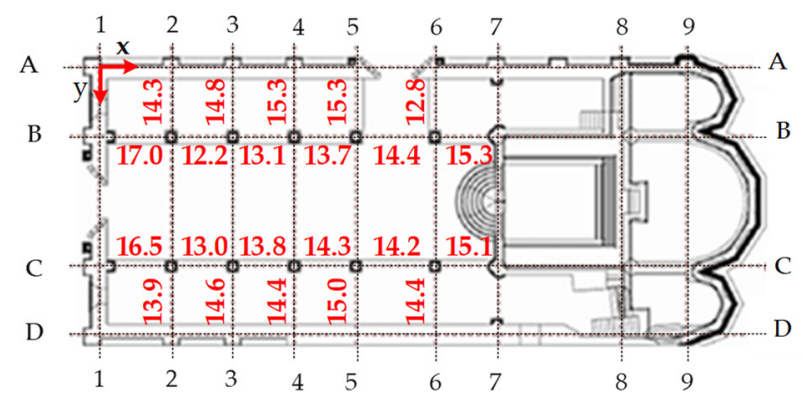

(a)

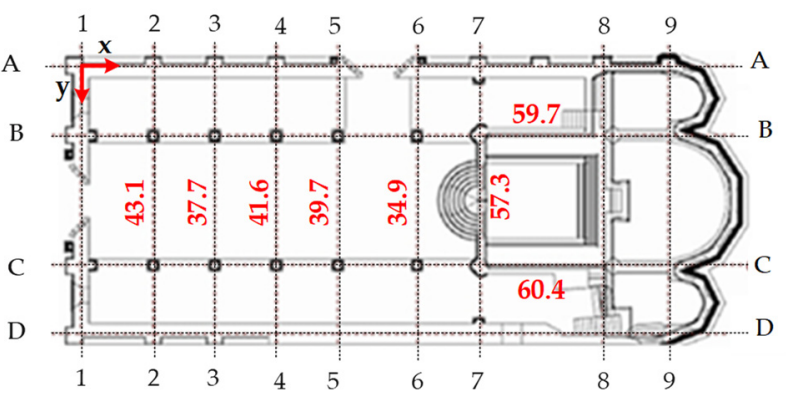

(b)

Figure 8. Stress levels obtained in the (a) aluminum tie rods (level R2) and (b) cast steel tie rods (level R4) in the Cathedral of St. James in Šibenik (all indicated values are in MPa).

Since the foundation conditions are not known, for the initial numerical model, instead of the foundation strips under the walls and columns, hinge boundary conditions were defined.

\subsection{Results of the Initial Numerical Model of the Cathedral}

On the initial numerical model for which the hinge boundary condition was proposed and elasticity modulus of stone masonry as $20 \mathrm{GPa}$, the numerical modal analysis was performed through which the natural frequency values and mode shapes were obtained. To assess how well the initial numerical model describes the real state of the structure, the numerically obtained natural frequency values (Table 3) were compared with the experimentally obtained one (Table 1). Based on the obtained natural frequency error 
(Table 3), it can be concluded that the initial numerical model deviates significantly from the real state of the structure, where the deviation in the natural frequencies values is up to $16.5 \%$, but the mode shapes are visually well correlated.

Table 3. Comparison of the numerically $\left(\mathrm{f}_{\mathrm{n}}^{\text {num }}\right)$ and experimentally $\left(\mathrm{f}_{\mathrm{n}}^{\exp }\right)$ obtained natural frequency values.

\begin{tabular}{ccccc}
\hline $\begin{array}{c}\text { Mode, } \\
\mathbf{n}\end{array}$ & Direction & $\begin{array}{c}\mathbf{f}_{\mathbf{n}}^{\text {num }} \\
\mathbf{( H z )}\end{array}$ & $\begin{array}{c}\mathbf{f}_{\mathbf{n}}^{\text {exp }} \\
\mathbf{( H z )}\end{array}$ & $\begin{array}{c}\text { Natural } \\
\text { Frequency } \\
\text { Error } \mathbf{( \% )}\end{array}$ \\
\hline 1 & Bending around x axis, symmetrical & 3.13 & 3.75 & 16.5 \\
2 & Bending around x axis, antimetrical & 5.14 & 5.55 & 6.5 \\
3 & Second bending mode shape around $x$ axis & 6.24 & 5.85 & 6.3 \\
\hline
\end{tabular}

Given the natural frequency error (Table 3) in order to approach the determination of stress levels in tie rods due to the action of seismic load, the global numerical model of the cathedral needs to be updated. The next section describes the selection of the parameters used for updating the model, and the results of the model updating performed on the global numerical model of the cathedral.

\section{Finite Element Model Updating}

First, the sensitivity analysis was performed to determine the influence of different structural parameters on structural dynamic behavior. The geometrical characteristics of the structure are well known from the 3D scan. As for the material characteristics, the only unknown parameter is the elasticity modulus of the stone masonry. Besides, the principle of the foundation is also unknown, but geotechnical soil testing data are available [50]. Therefore, the soil stiffness obtained by geotechnical testing varies significantly for certain parts of the area where the cathedral is located, so the boundary conditions are taken as additional model updating parameters. As there were only two updating parameters selected, the manual model update was performed in such a way that the value of the elasticity modulus of stone masonry $\left(\mathrm{E}_{\mathrm{n}}^{\text {num }}\right)$ was iterated for two boundary conditions-hinge and clamped (Table 4). The interaction between the structure and the ground is described by the same boundary conditions. The modulus of the elasticity of stone masonry $\left(\mathrm{E}_{\mathrm{n}}^{\text {num }}\right)$ was iterated with the step of approximately $0.5 \mathrm{GPa}$ to $2 \mathrm{GPa}$ within the lower bound of $20 \mathrm{GPa}$ and upper bound of the $35 \mathrm{GPa}$.

Table 4. Changing of the natural frequency values ( $\left.f_{n}^{\text {num }}\right)$ depending on the stone elasticity modulus $\left(E_{n}^{\text {num }}\right)$ for the different types of boundary conditions.

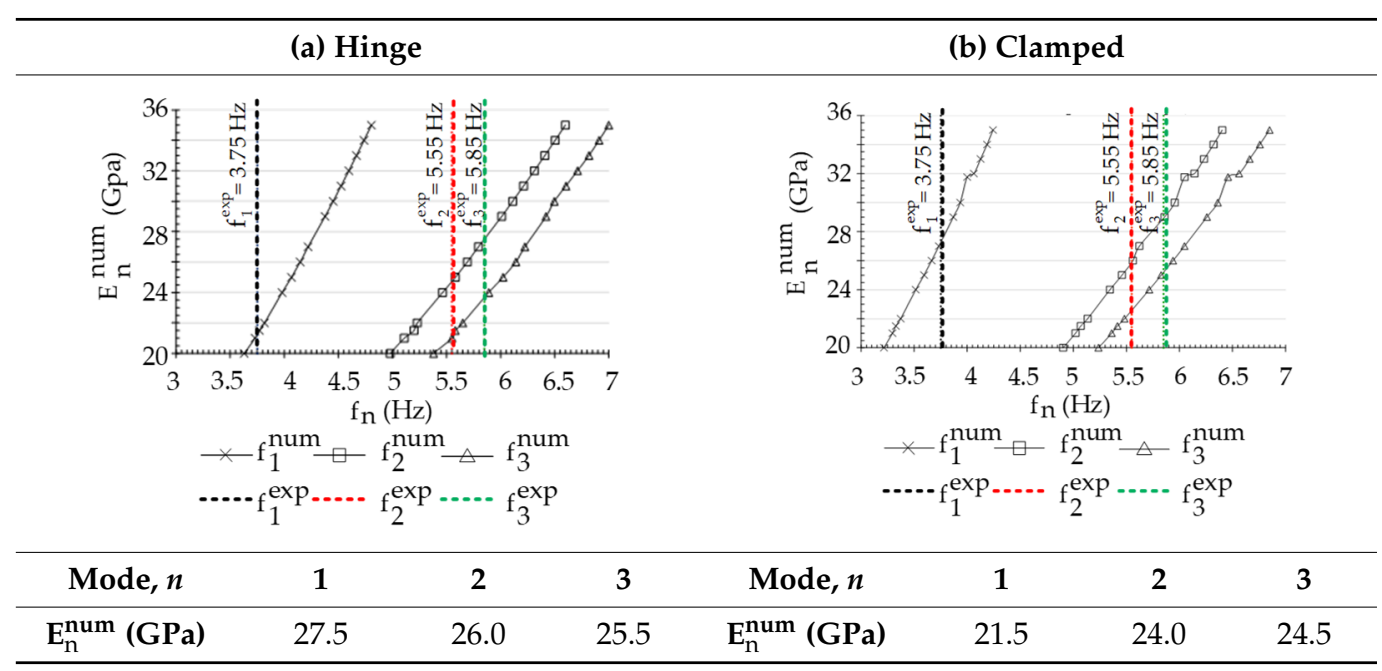


Table 4. Cont.

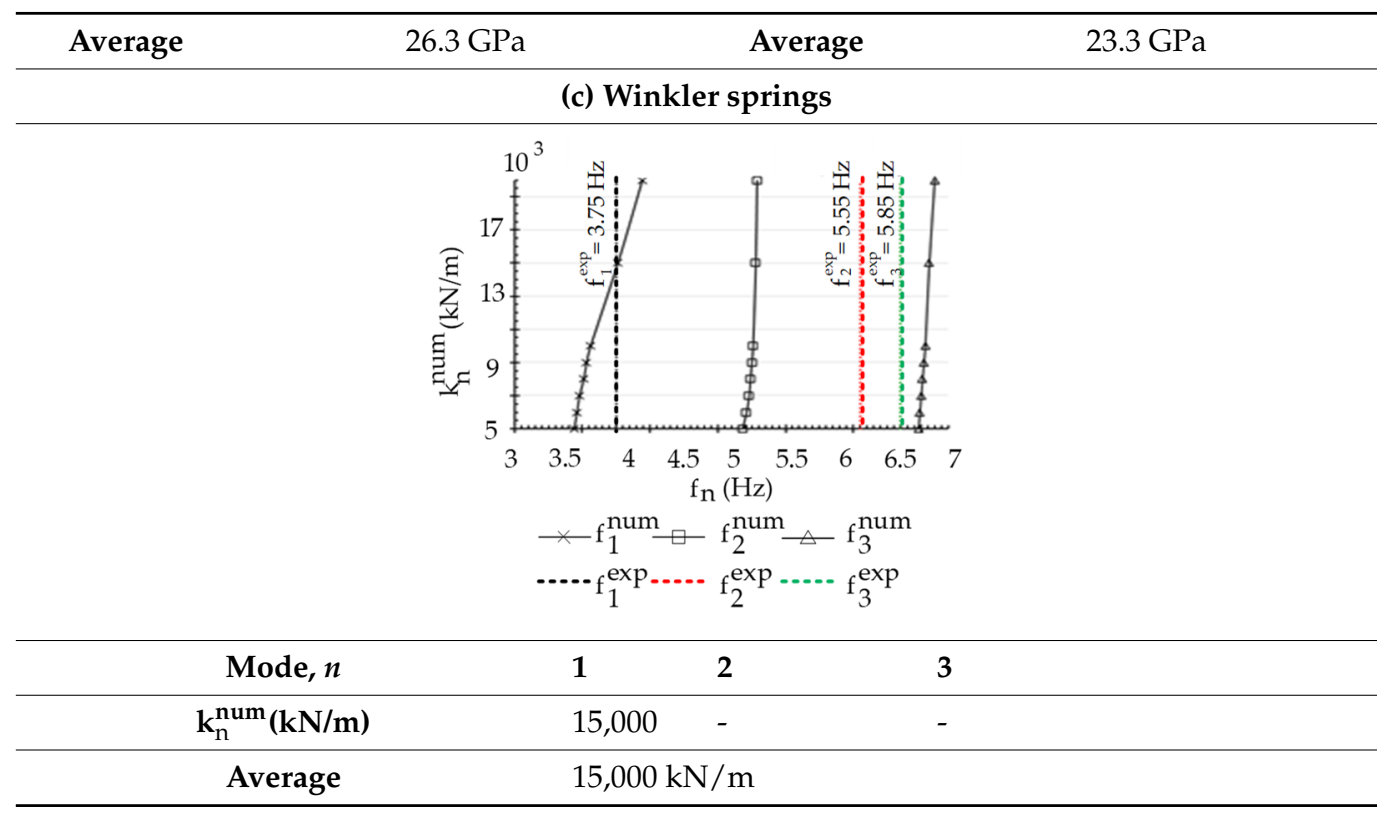

\subsection{Manual FEMU}

Considering the different types of boundary conditions-hinge and clamped-the elasticity modulus value was updated. The obtained changes of the first three natural frequencies for different values of the dynamic elasticity modulus and for a different type of boundary condition are summed in Table 4 . The experimentally obtained natural frequency values are indicated in the graph by the dashed line, where the first experimentally obtained natural frequency is shown in black, the second in red and the third in green, respectively. Following the known experimental values of natural frequency from the graph (Table 4), the values of the elasticity modulus were read. For each of the three modes for hinge and clamped boundary conditions these values are very close. The final value of the elasticity modulus ( $E_{n}^{\text {num }}$ ) was determined as the average value of the read values. For hinge boundary conditions this value is $26.3 \mathrm{GPa}$, with a standard deviation of $1.04 \mathrm{GPa}$. For the clamped boundary condition this value is $23.2 \mathrm{GPa}$ while the standard deviation is 1.44 GPa. Since in the case of the boundary conditions which consider the soil stiffness, it is assumed that the value of the elasticity modulus is close to the values read for the hinge and the clamped boundary conditions, its value was assumed as $25 \mathrm{GPa}$.

For the assumed value of the elasticity modulus, an analysis of the changing natural frequency values depending on the change of the spring stiffness was performed. Soil stiffness was defined by line springs where the spring stiffness was iterated between $5,000-20,000 \mathrm{kN} / \mathrm{m}$, which corresponds to the soil characteristics determined by geotechnical testing. Due to the simplicity of the FE model of the cathedral, the same spring stiffness values are defined for each degree of freedom. Based on the performed iteration procedure, it can be concluded that the second and third modes are insensitive to spring stiffness.

The sum of the performed FEMU iteration steps and results can be found in the following table (Table 4).

\subsection{Evaluation of the Updated Numerical Model Using Modal Assurance Factor Criteria (MAC)}

In this section previously updated numerical models based on the variation of elasticity modulus and boundary conditions will be compared. The first numerical model (1.HBC) describes hinge boundary conditions with an adopted elasticity modulus $\mathrm{E}=26.3 \mathrm{GPa}$. The second numerical model (2.CBC) describes the clamped boundary conditions with an adopted elasticity modulus $\mathrm{E}=23.2 \mathrm{GPa}$. The third numerical model (3.ELS) describes boundary conditions approximated by elastic springs with adopted stiffness $\mathrm{k}=15,000 \mathrm{kN} / \mathrm{m}$ and elasticity modulus $\mathrm{E}=25 \mathrm{GPa}$. The comparison will be based on the MAC factor criteria 
Equation (1) of experimentally obtained mode shapes of the structure with the mode shapes of the corresponding updated numerical models. The characteristics of the estimated numerical models are summarized in Table 5 .

Table 5. Sum of the characteristics of the numerical models.

\begin{tabular}{cccc}
\hline Model & Boundary Condition & $\begin{array}{c}\mathrm{E}_{\mathbf{n}}^{\text {num }} \\
(\mathrm{GPa})\end{array}$ & $\begin{array}{c}\mathbf{k}_{\mathbf{n}}^{\text {num }} \\
\mathbf{( N / m})\end{array}$ \\
\hline 1. HBC & $\mathrm{u}_{\mathrm{x}}, \mathrm{u}_{\mathrm{y}}, \mathrm{u}_{\mathrm{z}}=0$ & 26.5 & - \\
\hline 2. CBC & $\begin{array}{c}\mathrm{u}_{\mathrm{x}}, \mathrm{u}_{\mathrm{y}}, \mathrm{u}_{\mathrm{z}}=0 \\
\varphi_{\mathrm{x}}, \varphi_{\mathrm{y}}, \varphi_{\mathrm{z}}=0\end{array}$ & 23.2 & - \\
\hline 3. ELS & $\mathrm{u}_{\mathrm{x}}, \mathrm{u}_{\mathrm{y}}=0$ & 25 & 15,000 \\
\hline
\end{tabular}

For simplicity, the comparison of the experimentally, $\phi_{n, i}^{\exp }$, and numerically, $\phi_{n, j}^{\text {num }}$ obtained mode shapes were performed at seven measurement points in the middle of the arches which separate the roof slabs of the middle nave (Figure 9). In this way, the MAC Equation (1) factor values of the observed mode shapes were obtained (Table 5).

$$
\operatorname{MAC}\left(\phi_{n, i}^{\exp }, \phi_{n, j}^{\text {num }}\right)=\frac{\left|\left(\phi_{n, i}^{\exp }\right)^{\mathrm{t}} \phi_{n, j}^{\text {num }}\right|^{2}}{\left(\left(\phi_{n, i}^{\exp }\right)^{\mathrm{t}}\left(\phi_{n, i}^{\exp }\right)\right) \cdot\left(\left(\phi_{n, j}^{\text {num }}\right)^{\mathrm{t}}\left(\phi_{n, j}^{\text {num }}\right)\right)}
$$

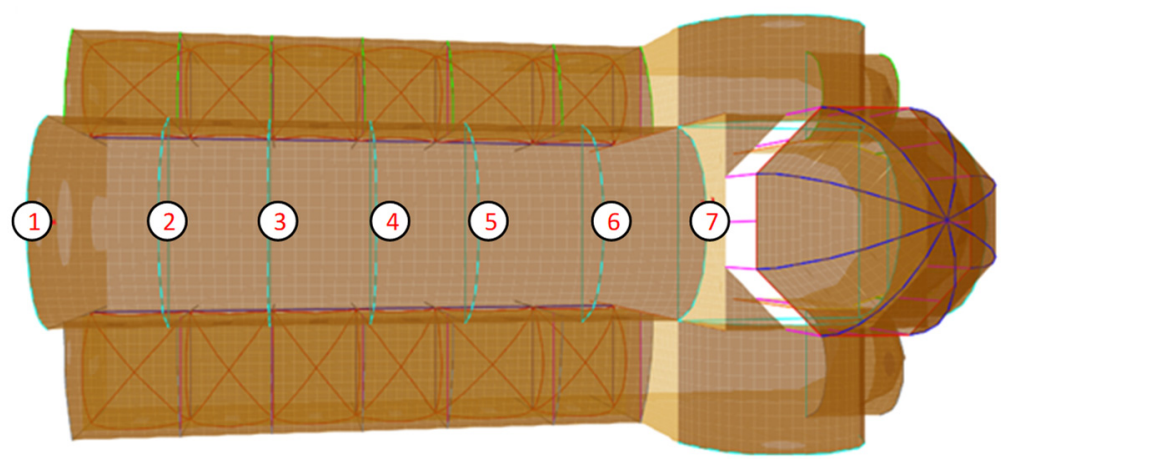

Figure 9. Measuring points in which displacements are analyzed and compared.

Based on the MAC factor, the model that the beast corresponds to the real state of the structure (the model whose MAC factor assumes the highest values for all three mode shapes) will be selected.

A graphical representation of the experimentally obtained normalized mode shape vector, $\phi_{n, i}^{\exp }$ of the seven selected points is given in Figure 10. Since in each of the mode shapes the dominant horizontal displacement is in the y direction, the displacement in the $\mathrm{x}$ and $\mathrm{z}$ directions is negligible. The comparison of mode shapes will be performed based on the dominant direction $\mathrm{y}$. 


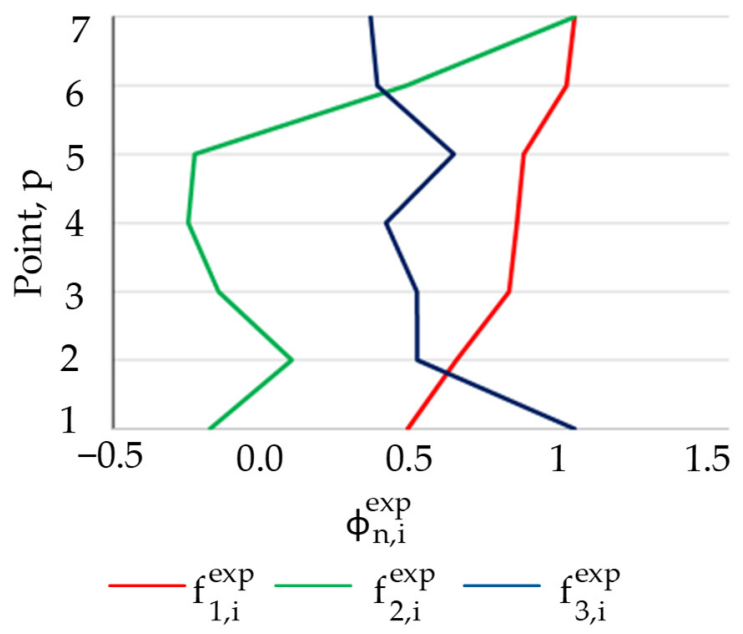

Figure 10. Experimentally obtained normalized mode shape vector for the selected measurement points $\mathrm{p}(1-7)$.

\subsection{Results of the Evaluation of the Numerical Model}

The numerical mode shape vector, $\phi_{n, j}^{\text {num }}$, for each developed model (Table 5) for three mode shapes were read from the numerical model and afterward normalized to the unit (Table 6a). Using MAC factor the numerically obtained mode shape vector $\left(\phi_{n, j}^{\text {num }}\right)$ was compared to the experimentally obtained one $\left(\phi_{n, j}^{\exp }\right)$ (Table 6b). The graphical representation of the obtained MAC factor for each of the developed numerical models is shown in Table 6. From the obtained MAC matrix (Table 6b) an excellent correlation of numerical model 1 (HBC) with the real state of structure can be noticed. The MAC factors for all three mode shapes take extremely large values. From the obtained MAC matrix for the numerical model 2, CBC, it can be seen that the MAC factors for first and third mode shapes have very high values, while for the second mode shapes this value is much lower. As for the third numerical model (3. ELS), it can be seen that the first numerically obtained mode shape vector, of all developed numerical models best correlate with the experimentally obtained one. However, considering the second and third numerically obtained mode shape vectors there is a significant deviation. This is supported by the fact that only the first numerically obtained mode shape vector was achieved for the selected spring stiffness. For the second mode shape vector, the natural frequency value deviated significantly from the experimentally determined value. In addition to the deviation of the natural frequency, the MAC factor is very low and is only 0.17 . In the third mode shapes, for assumed soil stiffness, a frequency value slightly closer to the experimentally determined value was achieved, but still insufficient to make the MAC factor value satisfactory [51].

As the MAC factor values for numerical model 1.HBC achieve the highest values for all three mode shapes, it was selected as the model on which an analysis of force in tie rods for seismic action will be performed. 
Table 6. Sum of the results of the evaluation of updated numerical model using MAC factor criteria.

Nonerical Model

(a) Numerically obtained normalized mode shape vector for the selected measurement points (1-7)

\begin{tabular}{|c|c|c|c|c|c|c|c|c|c|c|c|}
\hline \multirow{3}{*}{$\mathrm{MAC}_{\mathrm{M} 1-\mathrm{E}}=$} & 0.988 & 0.498 & $0.626]$ & \multirow{3}{*}{$\mathrm{MAC}_{\mathrm{M} 2-\mathrm{E}}=$} & 0.984 & 0.313 & $0.608]$ & \multirow{3}{*}{$\mathrm{MAC}_{\mathrm{M} 3-\mathrm{E}}=$} & 0.996 & 0.224 & 0.661 \\
\hline & 0.596 & 0.943 & 0.185 & & 0.780 & 0.235 & 0.971 & & 0.780 & 0.166 & 0.766 \\
\hline & 0.805 & 0.195 & 0.816 & & 0.863 & 0.245 & 0.870 & & 0.891 & 0.596 & 0.722 \\
\hline
\end{tabular}

(b) MAC matrices for comparison of the numerically and experimentally obtained normalized mode shape vectors for the selected measurement points (1-7)
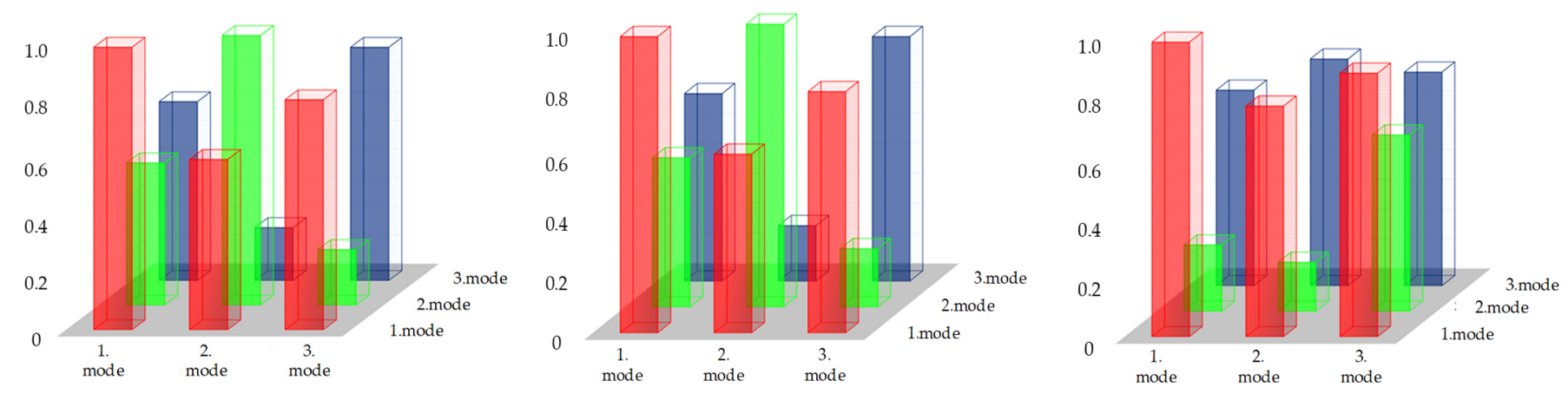

(c) Graphical representation of MAC matrices for comparison of the numerically and experimentally obtained normalized mode shape vectors for the selected measurement points (1-7)

\section{Analysis of Seismic Action of the Tie Rod Systems}

After the numerical model and its properties were obtained, the seismic performance assessment of the global numerical model was performed using the modal response spectrum analysis according to the EN 1998-1:2004 [52]. For the defined the load combination, which includes the dominant action of the earthquake in the x-direction (ERTHSTX) and $y$-direction (ERTHSTY), the values of the force in the tie rod were determined. The load combinations for dominant seismic actions in the $\mathrm{x}$ (Equation (2)) and y directions (Equation (3)) include the following load patterns: self-weight (dead load) (SW), additional constant load $(\mathrm{G})$, service load $(\mathrm{Q})$, seismic action in the $\mathrm{x}$-direction (ERTHX), and seismic action in the y-direction (ERTHY). The load combination for the dominant seismic action in the x-direction (ERTHSTX) contains all load patterns multiplied by the scale factor 1.0, except for the load pattern for the seismic action in the y-direction and the service load. The load pattern for the seismic action in the y-direction and the service load were multiplied by the scale factor 0.3. The load combination for the dominant seismic action in the y-direction (ERTHSTY) contains the same load pattern, except for the service load, and the load pattern for seismic action in the $x$-direction was also multiplied by the scale factor 0.3 instead of the y-direction. 


$$
\begin{aligned}
& \text { ERTHSTX }=1.0 \cdot \mathrm{SW}+0.3 \cdot \mathrm{Q}+1.0 \cdot \mathrm{G}+1.0 \cdot \mathrm{ERTHX}+0.3 \cdot \text { ERTHY } \\
& \text { ERTHSTX }=1.0 \cdot \mathrm{SW}+0.3 \cdot \mathrm{Q}+1.0 \cdot \mathrm{G}+0.3 \cdot \mathrm{ERTHX}+1.0 \cdot \mathrm{ERTHY}
\end{aligned}
$$

According to the available map of the seismic area in Croatia and Šibenik, expected horizontal peak soil acceleration was read. For the return period of 95 years, its value is $0.094 \mathrm{~g}$, while for the return period of 475 years, its value is 0.189 . According to the defined soil type category $C$, the values of elastic response spectrum type 1 were determined. Considering the type of construction, a behavior factor $\mathrm{q}$ of 1.5 was assumed for the project spectrum. The seismic action was analyzed for two axes-the $\mathrm{x}$ axis and the $\mathrm{y}$ axis. The deformation of the $3 \mathrm{~d}$ model of the updated finite element model of the cathedral due to seismic action in the $\mathrm{x}$ and $\mathrm{y}$ directions is shown in the following (Figure 11).

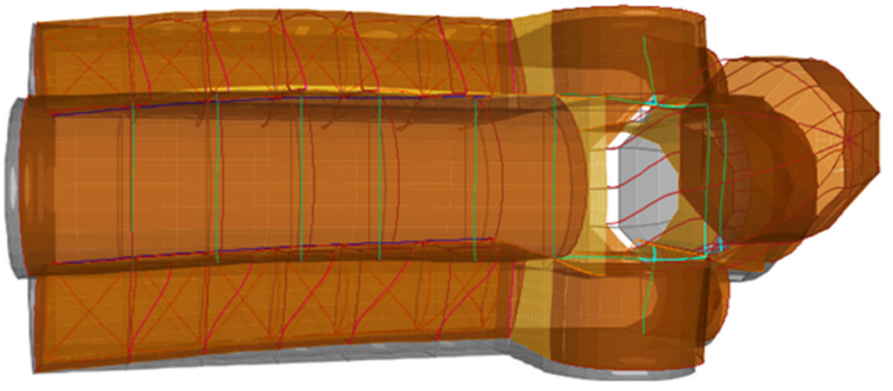

(a)

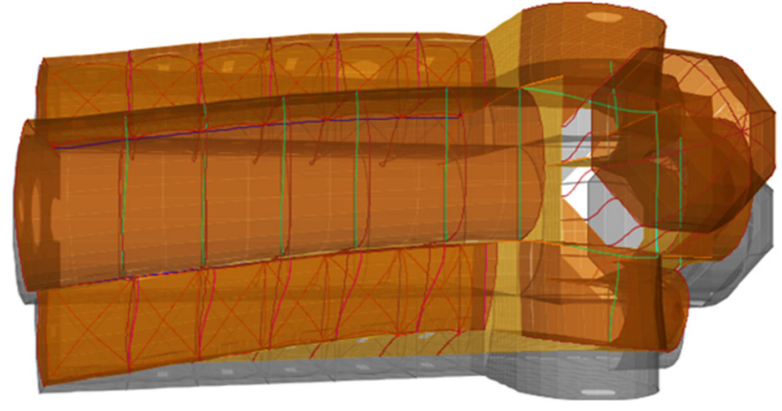

(b)

Figure 11. Deformation of the model updated finite element model of the cathedral due to seismic actions in (a) $x$ and (b) y direction.

After the definition of the seismic action the stress levels in the tie rods were determined (Tables 7 and 8). The graphical comparison of the stress levels in the aluminum tie rods at the level R2 is shown in Figures 12 and 13, while for the cast steel tie rods graphical comparison is shown in Figure 14.

Table 7. Values of forces and stress levels in the aluminum tie rods in the axis at the level $\mathrm{R} 2$ for the seismic action in the $\mathrm{x}$

\begin{tabular}{|c|c|c|c|c|c|c|c|c|c|c|c|}
\hline Tie Rod & $2 \mathrm{~A}-\mathrm{B}$ & $3 \mathrm{~A}-\mathrm{B}$ & $4 \mathrm{~A}-\mathrm{B}$ & $5 \mathrm{~A}-\mathrm{B}$ & $6 \mathrm{~A}-\mathrm{B}$ & 1-2 B & $2-3 \mathrm{~B}$ & $3-4 \mathrm{~B}$ & 4-5 B & 5-6 B & 6-7 B \\
\hline $\begin{array}{l}\text { Earthquake } \\
\text { Direction }\end{array}$ & $\begin{array}{c}\sigma_{\mathrm{n}} \\
(\mathrm{MPa})\end{array}$ & $\begin{array}{c}\sigma_{\mathrm{n}} \\
(\mathrm{MPa})\end{array}$ & $\begin{array}{c}\sigma_{\mathrm{n}} \\
(\mathrm{MPa})\end{array}$ & $\begin{array}{c}\sigma_{\mathrm{n}} \\
(\mathrm{MPa})\end{array}$ & $\begin{array}{c}\sigma_{\mathrm{n}} \\
(\mathrm{MPa})\end{array}$ & $\begin{array}{c}\sigma_{\mathrm{n}} \\
(\mathrm{MPa})\end{array}$ & $\begin{array}{c}\sigma_{\mathrm{n}} \\
(\mathrm{MPa})\end{array}$ & $\begin{array}{c}\sigma_{\mathrm{n}} \\
(\mathrm{MPa})\end{array}$ & $\begin{array}{c}\sigma_{\mathrm{n}} \\
(\mathrm{MPa})\end{array}$ & $\begin{array}{c}\sigma_{\mathrm{n}} \\
(\mathrm{MPa})\end{array}$ & $\begin{array}{c}\sigma_{\mathrm{n}} \\
(\mathrm{MPa})\end{array}$ \\
\hline$x$ & 15.68 & 16.26 & 16.84 & 16.84 & 14.10 & 18.92 & 14.16 & 15.36 & 15.32 & 16.72 & 17.79 \\
\hline $\mathrm{y}$ & 15.83 & 16.41 & 17.00 & 17.00 & 14.23 & 18.67 & 13.62 & 14.78 & 15.93 & 16.09 & 17.11 \\
\hline Tie rod & $2 \mathrm{C}-\mathrm{D}$ & $3 \mathrm{C}-\mathrm{D}$ & $4 \mathrm{C}-\mathrm{D}$ & $5 \mathrm{C}-\mathrm{D}$ & $6 \mathrm{C}-\mathrm{D}$ & $1-2 C$ & $2-3 C$ & $3-4 \mathrm{C}$ & $4-5 \mathrm{C}$ & 5-6 C & $6-7$ \\
\hline $\begin{array}{l}\text { Earthquake } \\
\text { Direction }\end{array}$ & $\begin{array}{c}\sigma_{n} \\
(\mathbf{M P a})\end{array}$ & $\begin{array}{c}\sigma_{\mathrm{n}} \\
(\mathrm{MPa})\end{array}$ & $\begin{array}{c}\sigma_{n} \\
(\mathbf{M P a})\end{array}$ & $\begin{array}{c}\sigma_{\mathrm{n}} \\
(\mathbf{M P a})\end{array}$ & $\begin{array}{c}\sigma_{\mathrm{n}} \\
(\mathrm{MPa})\end{array}$ & $\begin{array}{c}\sigma_{\mathrm{n}} \\
(\mathrm{MPa})\end{array}$ & $\begin{array}{c}\sigma_{\mathrm{n}} \\
(\mathrm{MPa})\end{array}$ & $\begin{array}{c}\sigma_{\mathrm{n}} \\
(\mathbf{M P a})\end{array}$ & $\begin{array}{c}\sigma_{n} \\
(\mathbf{M P a})\end{array}$ & $\begin{array}{c}\sigma_{\mathrm{n}} \\
(\mathrm{MPa})\end{array}$ & $\begin{array}{c}\sigma_{\mathrm{n}} \\
(\mathrm{MPa})\end{array}$ \\
\hline$x$ & 15.25 & 16.04 & 15.84 & 16.45 & 15.87 & 19.18 & 15.08 & 15.98 & 16.55 & 16.47 & 17.48 \\
\hline $\mathrm{y}$ & 15.39 & 16.18 & 15.98 & 16.60 & 16.01 & 18.45 & 14.51 & 15.38 & 15.92 & 15.85 & 16.81 \\
\hline
\end{tabular}
and $y$-direction.

Table 8. Values of forces and stress levels in the aluminum tie rod for the seismic action in $\mathrm{x}$ and $\mathrm{y}$-direction.

\begin{tabular}{ccccccccc}
\hline Tie Rod & 2 B-C & 3 B-C & 4 B-C & 5 B-C & 6 B-C & 7 B-C & 7-8 B & 7-8 C \\
\hline $\begin{array}{c}\text { Earthquake } \\
\text { Direction }\end{array}$ & $\begin{array}{c}\boldsymbol{\sigma}_{\mathbf{n}} \\
\mathbf{( M P a})\end{array}$ & $\begin{array}{c}\boldsymbol{\sigma}_{\mathbf{n}} \\
\mathbf{( M P a}\end{array}$ & $\begin{array}{c}\boldsymbol{\sigma}_{\mathbf{n}} \\
\mathbf{M P a})\end{array}$ & $\begin{array}{c}\boldsymbol{\sigma}_{\mathbf{n}} \\
\mathbf{( M P a}\end{array}$ & $\begin{array}{c}\boldsymbol{\sigma}_{\mathbf{n}} \\
(\mathbf{M P a})\end{array}$ & $\begin{array}{c}\boldsymbol{\sigma}_{\mathbf{n}} \\
(\mathbf{M P a})\end{array}$ & $\begin{array}{c}\boldsymbol{\sigma}_{\mathbf{n}} \\
(\mathbf{M P a})\end{array}$ & $\begin{array}{c}\boldsymbol{\sigma}_{\mathbf{n}} \\
(\mathbf{M P a})\end{array}$ \\
\hline $\mathrm{x}$ & 50.26 & 43.85 & 47.52 & 46.83 & 40.51 & 66.83 & 71.35 & 72.18 \\
\hline $\mathrm{y}$ & 49.54 & 45.10 & 46.82 & 47.23 & 44.06 & 67.86 & 68.56 & 70.39 \\
\hline
\end{tabular}




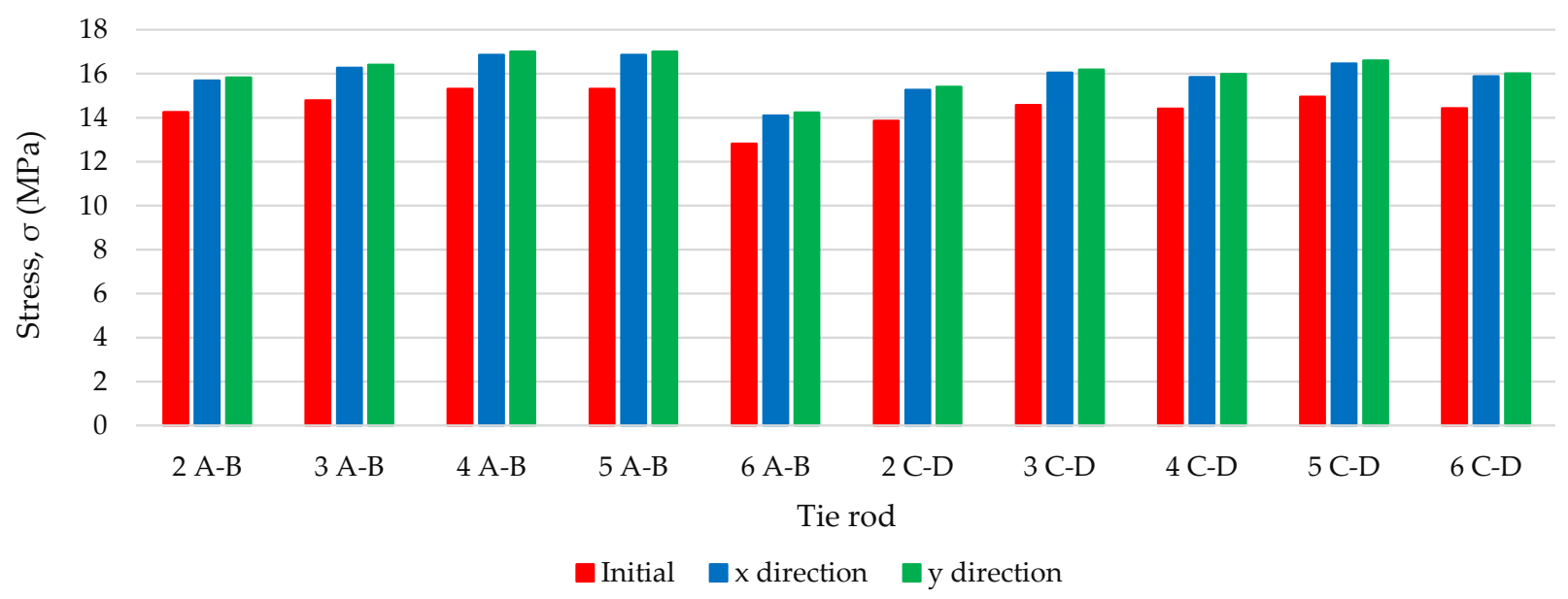

Figure 12. Graphical comparison of stress level in the aluminum tie rod in axis A-B and C-D at the level R2 for the initial state and seismic action in $\mathrm{x}$ and $\mathrm{y}$-direction.

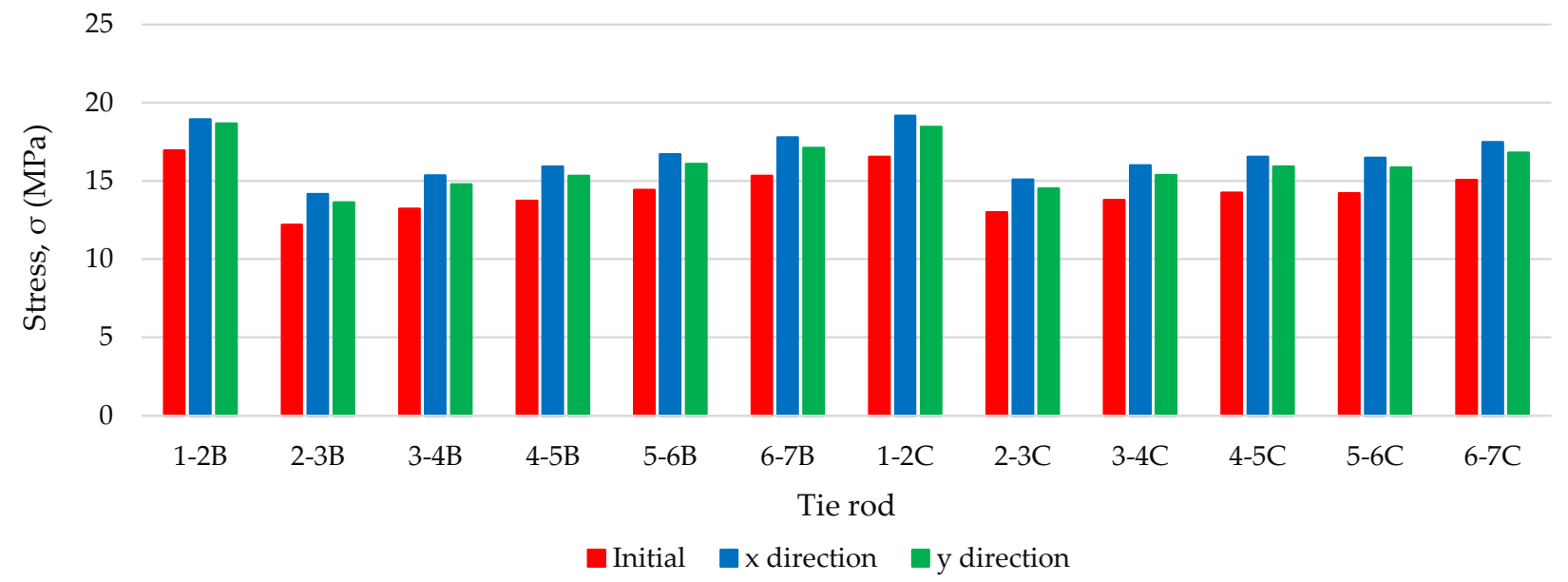

Figure 13. Graphical comparison of stress level in the aluminum tie rod in axis B and C at the level R2 for the initial state and seismic action in $\mathrm{x}$ and $\mathrm{y}$-direction.

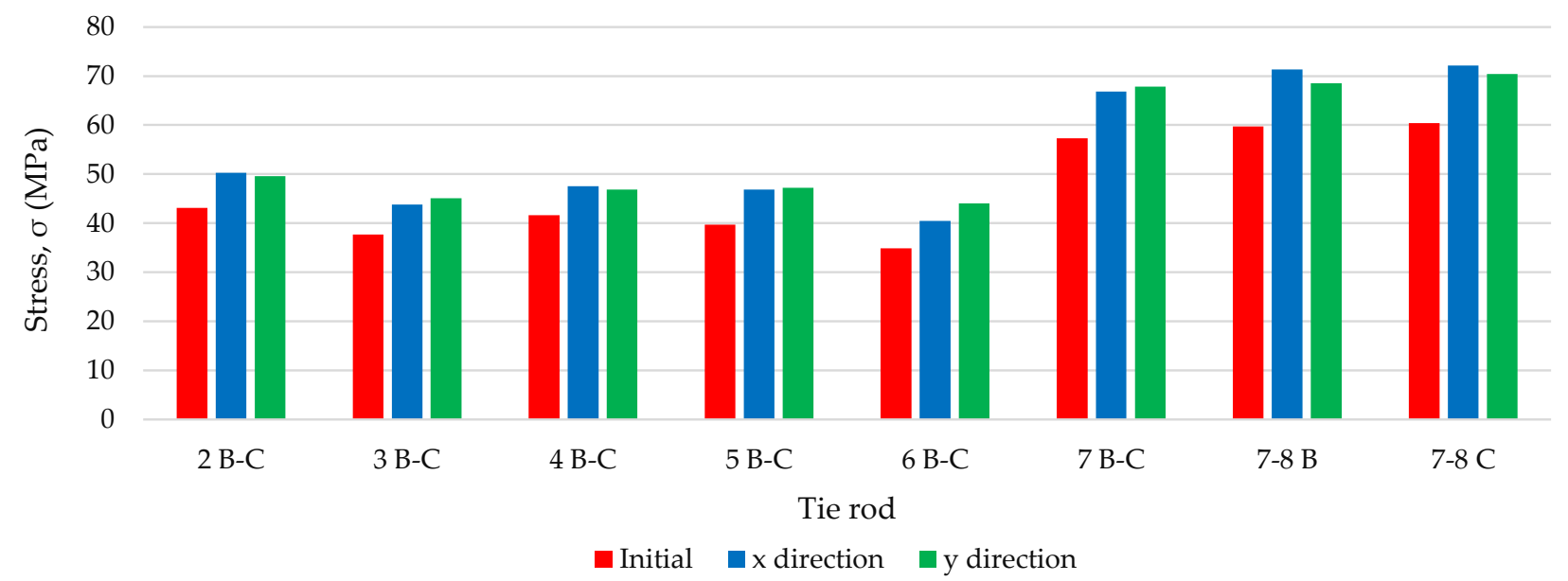

Figure 14. Graphical comparison of stress level in the cast steel tie rod in axis B-C, B and C at the level R4 for the initial state and seismic action in $\mathrm{x}$ and $\mathrm{y}$-direction. 


\section{Discussion and Conclusions}

This research presents the method for the analysis of the possibility of exceeding the load bearing capacity of tie rods in a historic building (Cathedral of St. James in Šibenik) under seismic action. The performed analysis is based on the combination of structural dynamic parameters obtained by the experimental on-site investigation and the finite element model updating (FEMU) procedure. In order to obtain the initial state of each aluminum and cast steel tie rod, the FEMU of each representative tie rod was performed by using the approach elaborated by the authors in [10]. Then, by using the elastic modulus of the stone masonry and the boundary conditions as the update parameters, the global numerical model of the cathedral was updated in order to obtain a representative global numerical model describing the real state of the structure. By subjecting the updated global numerical model to seismic load according to EN 1998-1:2004, the stress level in the tie rods was determined. Based on the obtained stress levels, it can be concluded that due to the seismic action, the axial forces in the tie-rods increase. For aluminum tie rods this increase was $13.25 \%$ with st. deviation $0.85 \%$ for seismic action in $\mathrm{x}$ direction. For seismic action in y direction, this increase was $10.80 \%$ with st. deviation of $0.63 \%$. The increase in the stress levels for cast steel tie rods was $16.15 \%$ with st. deviation of $1.15 \%$ for seismic action in $\mathrm{x}$ direction. For seismic action in the $\mathrm{y}$ direction, the increase in the stress level was $18.72 \%$ with a standard deviation of $3.99 \%$. For the seismic action in the $x$ direction, the tie rods in $x$ direction were activated more than the tie rods in $y$ direction. An analogous situation was observed in the case of seismic action in the y direction. Compared to their tensile strength, the maximum stress level in the tie rods induced by the seismic action was $36.1 \%$ in the case of the cast steel tie rod and $21.31 \%$ in the case of the aluminum tie rod. Based on the results of conducted research, it can be concluded that the proposed method is a viable solution for determination of the load bearing capacity of tie rods in historical buildings. Since the updating of the tie rods local model and the global cathedral model was performed by manual tuning, as well as the linking of the experimental and numerical data sets, it is recommended to perform the automatic updating of the finite element model by using some kind of computer intelligence algorithm in future. Additionally, since a linear model was used in this study, it is recommended to perform a nonlinear analysis in the following studies. Due to the possibility that the force values in the tie rods may change due to settlement, the authors recommend that this influence also be considered in the following studies.

Author Contributions: Conceptualization, S.E. and I.D.; methodology, S.E and I.D.; formal analysis, S.E. and I.D.; investigation, I.D. and D.D.; writing—original draft preparation, S.E.; writing-review and editing, S.E. and M.B.; visualization, S.E.; supervision, I.D. and D.D.; project administration, I.D. and D.D; funding acquisition, I.D., D.D. and M.B. All authors have read and agreed to the published version of the manuscript.

Funding: This research was funded by the European Union through the European Regional Development Fund's Competitiveness and Cohesion Operational Program, grant number KK.01.1.1.04.0041, project "Autonomous System for Assessment and Prediction of infrastructure integrity (ASAP)".

Institutional Review Board Statement: Not applicable.

Informed Consent Statement: Not applicable.

Data Availability Statement: Not applicable.

Conflicts of Interest: The authors declare no conflict of interest. The funders had no role in the design of the study; in the collection, analyses, or interpretation of data; in the writing of the manuscript, or in the decision to publish the results. 


\section{References}

1. Battista, L.A. De re Aedificatoria. 1565. Available online: https://warburg.sas.ac.uk/pdf/cnh1015b2214989.pdf (accessed on 23 August 2021).

2. Li, S.; Reynders, E.; Maes, K.; De Roeck, G. Vibration-based estimation of axial force for a beam member with uncertain boundary conditions. J. Sound Vib. 2013, 332, 795-806. [CrossRef]

3. Li, D.S.; Yuan, Y.Q.; Li, K.P.; Li, H.N. Experimental axial force identification based on modified Timoshenko beam theory. Struct. Monit. Maint. 2017, 4, 153-173. [CrossRef]

4. Li, S.; Josa, I.; Cavero, E. Post Earthquake Evaluation of Axial Forces and Boundary Conditions for High-Tension. In Proceedings of the 16th World Conference of Earthquake, Santiago, Chile, 3-9 January 2017.

5. Tullini, N. Bending tests to estimate the axial force in slender beams with unknown boundary conditions. Mech. Res. Commun. 2013, 53, 15-23. [CrossRef]

6. Calderini, C.; Piccardo, P.; Vecchiattini, R. Experimental Characterization of Ancient Metal Tie-Rods in Historic Masonry Buildings. Int. J. Arch. Heritage 2019, 13, 425-437. [CrossRef]

7. Duvnjak, I.; Damjanović, D.; Krolo, J. Structural health monitoring of cultural heritage structures: Applications on Peristyle of Diocletian's palace in Split. In Proceedings of the 8th European Workshop on Structural Health Monitoring, EWSHM 2016, Bilbao, Spain, 5-8 July 2016; Volume 4.

8. Collini, L.; Garziera, R.; Riabova, K. Vibration Analysis for Monitoring of Ancient Tie-Rods. Shock. Vib. 2017, $2017,1-11$. [CrossRef]

9. Gentilini, C.; Marzani, A.; Mazzotti, M. Nondestructive characterization of tie-rods by means of dynamic testing, added masses and genetic algorithms. J. Sound Vib. 2013, 332, 76-101. [CrossRef]

10. Duvnjak, I.; Ereiz, S.; Damjanović, D.; Bartolac, M. Determination of Axial Force in Tie Rods of Historical Buildings Using the Model-Updating Technique. Appl. Sci. 2020, 10, 6036. [CrossRef]

11. Friswell, M.; Mottershead, J.E. Finite Element Model Updating in Structural Dynamics; Springer: Dordrecht, The Netherlands, 1996; pp. 56-155.

12. Ismail, Z.; Kuan, K.K.; Yee, K.S.; Chao, O.Z. Examining the trend in loss of flexural stiffness of simply supported RC beams with various crack severity using model updating. Measurement 2014, 50, 43-49. [CrossRef]

13. Oh, B.K.; Kim, D.; Park, H.S. Modal Response-Based Visual System Identification and Model Updating Methods for Building Structures. Comput. Civ. Infrastruct. Eng. 2016, 32, 34-56. [CrossRef]

14. Zhou, L.; Wang, L.; Chen, L.; Ou, J. Structural finite element model updating by using response surfaces and radial basis functions. Adv. Struct. Eng. 2016, 19, 1446-1462. [CrossRef]

15. Kim, S.; Kim, N.; Park, Y.-S.; Jin, S.-S.; Park, K.; Jin, A. Sequential Framework for Improving Identifiability of FE Model Updating using Static and Dynamic Data. Sensors 2019, 19, 5099. [CrossRef]

16. Ye, S.; Lai, X.; Bartoli, I.; Aktan, A.E. Technology for condition and performance evaluation of highway bridges. J. Civ. Struct. Health Monit. 2020, 10, 573-594. [CrossRef]

17. Shahbaznia, M.; Dehkordi, M.R.; Mirzaee, A. An Improved Time-Domain Damage Detection Method for Railway Bridges Subjected to Unknown Moving Loads. Period. Polytech. Civ. Eng. 2020, 64, 928-938. [CrossRef]

18. Luo, X.; Li, X.; Fu, X.; Gu, L. Research on Bridge Structural Health Assessment Based on Finite Element Analysis. Teh. Vjesn.-Tech. Gaz. 2020, 27, 96-105. [CrossRef]

19. Cui, Y.; Lu, W.; Teng, J. Updating of structural multi-scale monitoring model based on multi-objective optimisation. Adv. Struct. Eng. 2019, 22, 1073-1088. [CrossRef]

20. Nguyen, A.; Kodikara, K.T.L.; Chan, T.; Thambiratnam, D. Deterioration assessment of buildings using an improved hybrid model updating approach and long-term health monitoring data. Struct. Health Monit. 2018, 18, 5-19. [CrossRef]

21. Pachón, P.; Castro, R.; García, M.E.P.; Compán, V.; Puertas, E.E. Torroja's bridge: Tailored experimental setup for SHM of a historical bridge with a reduced number of sensors. Eng. Struct. 2018, 162, 11-21. [CrossRef]

22. Altunişik, A.C.; Okur, F.Y.; Genç, A.F.; Günaydin, M.; Adanur, S. Automated Model Updating of Historical Masonry Structures Based on Ambient Vibration Measurements. J. Perform. Constr. Facil. 2018, 32, 04017126. [CrossRef]

23. Cheng, X.; Dong, J.; Han, X.; Fei, Q. Structural Health Monitoring-Oriented Finite-Element Model for a Large Transmission Tower. Int. J. Civ. Eng. 2018, 16, 79-92. [CrossRef]

24. Venanzi, I.; Kita, A.; Cavalagli, N.; Ierimonti, L.; Ubertini, F. Earthquake-induced damage localization in an historic masonry tower through long-term dynamic monitoring and FE model calibration. Bull. Earthq. Eng. 2020, 18, 2247-2274. [CrossRef]

25. Ye, X.; Chen, B. Model updating and variability analysis of modal parameters for super high-rise structure. Concurr. Comput. Pr. Exp. 2019, 31, 1-11. [CrossRef]

26. Astroza, R.; Ebrahimian, H.; Li, Y.; Conte, J.P. Bayesian nonlinear structural FE model and seismic input identification for damage assessment of civil structures. Mech. Syst. Signal Process. 2017, 93, 661-687. [CrossRef]

27. Moravej, H.; Chan, T.H.T.; Nguyen, K.-D.; Jesus, A. Vibration-based Bayesian model updating of civil engineering structures applying Gaussian process metamodel. Adv. Struct. Eng. 2019, 22, 3487-3502. [CrossRef]

28. Tran-Ngoc, H.; Khatir, S.; De Roeck, G.; Bui-Tien, T.; Nguyen-Ngoc, L.; Wahab, M.A. Model Updating for Nam O Bridge Using Particle Swarm Optimization Algorithm and Genetic Algorithm. Sensors 2018, 18, 4131. [CrossRef] 
29. Nie, R.-F.; Huang, Y.-J.; Li, S.-H. In-Service Condition Assessment of Long-Span Bridges Based on Traffic Load Effects Using Monitoring Data. Staveb. Obzor-Civil Eng. J. 2018, 27, 450-457. [CrossRef]

30. Naranjo-Pérez, J.; Jiménez-Alonso, J.F.; Pavic, A.; Sáez, A. Finite-element-model updating of civil engineering structures using a hybrid UKF-HS algorithm. Struct. Infrastruct. Eng. 2021, 17, 620-637. [CrossRef]

31. Pacheco-Torgal, F.; Melchers, R.; Shi, X.; De Belie, N.; Van Tittelboom, K.; SaezEds, A. Eco-Efficient Repair and Rehabilitation of Concrete Infrastructure; Woodhead Publishing (Elsevier): Cambridge, UK, 2017.

32. Lulić, L.; Ožić, K.; Kišiček, T.; Hafner, I.; Stepinac, M. Post-Earthquake Damage Assessment-Case Study of the Educational Building after the Zagreb Earthquake. Sustainability 2021, 13, 6353. [CrossRef]

33. Livingston, R.A. Nondestructive Testing of Historic Structures. Arch. Mus. Inform. 1999, 13, 249-271. [CrossRef]

34. Chastre, C.; Ludovico-Marques, M. Nondestructive testing methodology to assess the conservation of historic stone buildings and monuments. In Handbook of Materials Failure Analysis; Elsevier BV: New York, NY, USA, 2018; pp. 255-294.

35. Kujawa, M.; Lubowiecka, I.; Szymczak, C. Finite element modelling of a historic church structure in the context of a masonry damage analysis. Eng. Fail. Anal. 2020, 107, 104233. [CrossRef]

36. D'Ayala, D.F. Numerical Modelling of Masonry Structures. Structures E Construction in Historic Building Conservation; Wiley: Hoboken, NJ, USA, 2007; pp. 151-172. [CrossRef]

37. Werkle, H. Modelling of connections between dissimilar finite element domains. Appl. Sci. 2002, 77, 78476.

38. Caliò, I.; Cannizzaro, F.; Marletta, M. A Discrete Element for Modeling Masonry Vaults. Adv. Mater. Res. 2010, 133-134, 447-452. [CrossRef]

39. Erenoglu, R.C.; Erenoglu, O.; Arslan, N. Accuracy Assessment of Low Cost UAV Based City Modelling for Urban Planning. Teh. Vjesn.-Tech. Gaz. 2018, 25, 1708-1714. [CrossRef]

40. Mader, D.; Blaskow, R.; Westfeld, P.; Weller, C. Potential of Uav-Based Laser Scanner and Multispectral Camera Data in Building Inspection. ISPRS-Int. Arch. Photogramm. Remote. Sens. Spat. Inf. Sci. 2016, XLI-B1, 1135-1142. [CrossRef]

41. Kerle, N.; Nex, F.; Gerke, M.; Duarte, D.; Vetrivel, A. UAV-Based Structural Damage Mapping: A Review. ISPRS Int. J. Geo-Inform. 2019, 9, 14. [CrossRef]

42. Kuczyńska, G.; Stawska, M.; Walicka, A. Modern geodetic techniques in the monitoring of historic buildings. E3S Web Confer. 2019, 97, 04043. [CrossRef]

43. Bayraktar, A.; Türker, T.; Sevım, B.; Altunişik, A.C.; Yildirim, F. Modal Parameter Identification of Hagia Sophia Bell-Tower via Ambient Vibration Test. J. Nondestruct. Eval. 2009, 28, 37-47. [CrossRef]

44. Atamturktur, S.; Pavic, A.; Reynolds, P.; Boothby, T. Full-Scale Modal Testing of Vaulted Gothic Churches: Lessons Learned. Exp. Tech. 2009, 33, 65-74. [CrossRef]

45. Binante, V.; Girarrdi, M.; Padovani, C.; Pasquinelli, G.; Pellegrini, D.; Porcelli, M.; Robol, L. Nosa—Itaca Documentation; Version 1.1; Istituto di Scienza e T Tecnologie dell'Informazione "Alessandro Faedo": Pisa, Italy, 2017.

46. Luong, H.T.; Zabel, V.; Lorenz, W.; Rohrmann, R.G. Vibration-based Model Updating and Identification of Multiple Axial Forces in Truss Structures. Procedia Eng. 2017, 188, 385-392. [CrossRef]

47. Ebrahimian, H.; Astroza, R.; Conte, J.P.; Papadimitriou, C. Nonlinear Model Inversion Method for Joint System Parameter, Noise, and Input Identification of Civil Structures. Procedia Eng. 2017, 199, 924-929. [CrossRef]

48. Ding, W.; Guo, Q. Application of Finite Element Method in Large-span Beam Bridge. In Proceedings of the 2016 International Conference on Engineering and Technology Innovations, Wuhan, China, 26-27 March 2016; p. 296. [CrossRef]

49. Ereiz, S.; Duvnjak, I.; Damjanović, D.; Krolo, J.; Bartolac, M. Analysis of Seismic Action of The Tie Rod System in Historical Buildings. In Proceedings of the 1st Croatian Conference on Earthquake Engineering, Zagreb, Croatia, 22-24 March 2021; pp. 1533-1543.

50. Jurić-Kačunić, D. Geotechnical Report; Department of Geotechnics, Faculty of Civil Engineering, University of Zagreb: Zagreb, Croatia, 2018.

51. Allemang, R.J.; Brown, D.L. A Correlation Coefficient for Modal Vector Analysis. In Proceedings of the 1st International Modal Analysis Conference (IMAC I), Orlando, FL, USA, 8-10 November 1982; pp. 110-116.

52. European Committee for Standardization (CEN). EN 1998-1:2004, Eurocode 8, Design of Structures for Earthquake Resistance, Part 1: General Rules, Seismic Actions and Rules for Buildings; CEN: Brussels, The Netherlands, 2004. 